\title{
PROTESTS IN THE UNITED STATES AGAINST BISMARCK'S ANTI-SOCIALIST LAW
}

During the summer of 1880, John Swinton, the American journalist and social reformer, made a forty-day tour of France and England. The most memorable event of the tour was the interview he had with Karl Marx during his visit to England, at the seashore resort of Ramsgate. Swinton was tremendously impressed by Marx and, in an account of the interview which he published in the New York Sun of September 6, 1880, he referred to him as "one of the most remarkable men of the day". One passage from Swinton's article, in particular, clearly illustrates the profound impact Marx had on him.

"I interrupted the revolutionist and philosopher in these fateful words: 'What is?' And it seemed as though his mind were inverted for a moment while he looked upon the roaring sea [...]. 'What is?' I had inquired, to which in deep and solemn tone, he replied: 'Struggle!' At first it seemed as though I had heard the echo of despair: but peradventure it was the law of life."

Marx obtained a copy of the Sun article, and in a letter from London, November 4, 1880, he thanked Swinton for his "friendly article", and sent him a copy of the French edition of the first volume of Capital. ${ }^{1}$ In the same letter, he wrote of the suffering of the Socialists in Bismarck's Germany as a result of the Iron Chancellor's AntiSocialist Law. He pointed out that Bismarck, having failed to destroy the German Social-Democratic Party, was now convinced that his repressive tactics would succeed if they were "applied on a large scale". The result was that the attacks on the Socialists were being spread throughout the entire country. Marx informed Swinton that he had just learned from his German friends that even though Bismarck's

1 In John Swinton's Paper of November 29, 1885, Swinton wrote that during his interview with Marx at Ramsgate in 1880, Marx had told him that if Capital were to be translated into English, the best procedure would be to translate it from the French edition. The text of Swinton's interview with Marx and his article on the translation of Capital are reprinted in Philip S. Foner, ed., When Karl Marx Died: Comments in 1883 (New York, 1973), pp. 240-44. 
policy had not destroyed and would not destroy the Socialist movement, it did, as they had written to him, "impose pecuniary sacrifices almost impossible to bear. To support the families ruined by the police, to keep alive the few papers left to us, to keep up the necessary communications by secret messengers, to fight the battle on the whole line - all this requires money. We are nearly exhausted and forced to appeal to our friends and sympathizers in other countries."

Marx assured Swinton that the Socialists and their sympathizers in Europe would do their part, and he urged the American to "organize a subscription in the United States". He added: "Even if the monetary result were not important, denunciations of Bismarck's new coup d'état in public meetings held by you, reported in the American press, reproduced on the other side of the Atlantic, would sorely hit the Pomeranian hobereau [country squire] and be welcomed by all the socialists of Europe." Marx urged Swinton to contact Friedrich A. Sorge, the last General Secretary of the First International, who lived at that time in Hoboken, New Jersey, for material. The day after he wrote to Swinton, Marx sent a letter to Sorge in which he reported that he had conveyed the desperate need "to John Swinton [...] and told him to apply to you for detailed information regarding German conditions". 1

There is no evidence either that Swinton ever replied to Marx, or that he and Sorge ever contacted each other. But Sorge did inform Marx that he had learned that Swinton had revealed that he had received a letter from Marx, but had said he could do nothing in the matter other than contribute about one hundred dollars personally to the cause. ${ }^{2}$ Marx did not refer directly to the matter in his one other letter to Swinton, June 2, 1881. It has therefore been assumed by the editors of the Marx-Swinton-Sorge correspondence that Marx's suggestion to Swinton came to naught, and that Bismarck's antiSocialist policy aroused little interest in the United States. Actually, while Marx did not mention it, Bismarck's anti-Socialist policy had, from its very inception, aroused considerable indignation in this country from Socialists, non-Socialist workers and liberal intellectuals. It took the form of protest meetings and the raising of funds for the relief of the victims of Bismarckism. Swinton, himself, was a leading figure in these protests. ${ }^{3}$

1 Karl Marx and Frederick Engels, Letters to Americans, 1848-1895 (New York, 1953), pp. 121-26. Marx's letter to Swinton was written in English.

${ }^{2}$ Sorge to Marx, February 10, 1881, Internationaal Instituut voor Sociale Geschiedenis, Amsterdam, copy in Institut für Marxismus-Leninismus, Berlin. ${ }^{3}$ In his biography of Swinton, Marc Ross writes that Swinton never participated in any "rally specifically for the purpose of demonstrating against Bismarck". 
Alarmed by the rise in the voting strength of the Socialists, by the growth of the Socialist press and institutions, and by the increase of Socialist influence in the trade unions, Prince Otto von Bismarck, Chancellor of the new German Empire, began to seek legal means to suppress the movement. After two attempts on Emperor Wilhelm's life, and in an atmosphere of hysteria against "Red Assassins" (even though neither of the two would-be assassins were associated with the Socialists), Bismarck succeeded in obtaining the passage of an Anti-Socialist Law by the Reichstag on October 19, 1878. It gave the government the authority to suppress all independent labor organizations, all political and economic associations of the Socialists, and all their newspapers, periodicals and printing presses. Socialist meetings were forbidden; the police were empowered to expel "Socialist agitators", and states could declare a state of siege in any areas of the country for periods of up to one year. While Socialist electoral activity was not forbidden, any efforts to make this right meaningful were severely hampered. The Anti-Socialist Law was renewed at its expiration in 1880 , and every two years thereafter until 1890. During this period, many leaders of the party were arrested, imprisoned or exiled. Hundreds of Socialist periodicals, associations and unions were suppressed by the police, and their assets were confiscated. ${ }^{1}$

The reaction to Bismarck's anti-Socialist policy in the non-Socialist press in the United States took varied forms. On the one hand, there were papers which supported the repressive measures. "Several more expulsions of Socialists have been ordered by the German government", declared the Christian Union, edited by Reverend Henry Ward Beecher, the former anti-slavery advocate who had become increasingly anti-labor in the post-war years. "So ought it be. We advise the American people to make certain that none of these expelled Socialists are welcomed in this country where they will spread their poisonous virus."2 The New York Tribune, now owned by the notorious "Robber Baron" Jay Gould, reprinted Beecher's editorial, and not only endorsed its advice to the American people, but even advocated the wholesale expulsion of those German Socialists already in this country. ${ }^{3}$

"John Swinton, Journalist and Reformer: The Active Years, 1857-1887" (unpublished Ph.D. thesis, New York University, 1968), p. 133. Actually, as we shall see, Swinton was a chief speaker at two such rallies.

1 Koppel S. Pinson, Modern Germany: Its History and Civilization (New York, 1954), pp 207-09.

2 Christian Union, December 1, 1878.

8 New York Tribune, December 4, 1878. 
The North American Review commented approvingly on an article it published by Moritz Busch, a German admirer of Bismarck, in which he insisted that Bismarck's policies merited the support of every American citizen. ${ }^{1}$

More common, however, was the view that Bismarck's anti-Socialism was a fundamental political error. Some newspapers expressed surprise that "this man of iron will and imperial resources", "so uniformly successful in his every undertaking", should make the error of publicly avowing "his fear of the Social Democracy of Germany". 2 Others reminded Bismarck that repression had rarely destroyed an idea, and that while Socialism was an evil, the Anti-Socialist Law would only make martyrs of the German Socialists and thus increase rather than reduce their influence. The New York Times advised the Chancellor that "free discussion" was "the true safety-valve of society," and the best antidote to the Socialists. ${ }^{3}$ Still another view expressed in the press was that Bismarck's policy should be condemned because, even though it was ostensibly directed against the Socialists, it opened the door to the destruction of the rights of any Germans who dared to challenge Bismarckism. ${ }^{4}$

An answer to the puzzle of why the Iron Chancellor should pursue an anti-Socialist policy could be found in an interview with Karl Marx published in the Chicago Tribune of January 5, 1879, and reprinted in several other papers. Toward the end of it, Marx pointed out that in an effort to impose a dictatorship of force upon the German people in order to continue his reign of oppression, Bismarck "had raised the ghost of Socialism" in an effort to instigate a premature uprising among the German people. Marx said that Bismarck's hope was that if the leaders of the Socialist Party were expelled from the country, the masses would rise up in revolt against his policies. He would then be in a position to impose his "blood and iron" policy upon the entire population and levy taxation to his heart's content. Forty-eight prominent German Socialists had already been expelled, Marx noted, but the Chancellor was disappointed because the people had had the good sense not to play into his hands by a premature revolt. ${ }^{5}$

\footnotetext{
1 Moritz Busch, "Prince Bismarck as a Friend of America and as a Statesman", in: North American Review, CXXXI (1880), pp. 3-13, 156-76.

2 Irish World (New York), October 21, 1878.

3 "Shutting the Safety-Valve", in: New York Times, September 27, 1878.

4 "Bismarck and German Socialism", in: Press (Philadelphia), September 5, 1878; "Insatiate Bismarck", in: Sun (New York), February 6, 1881.

- The Tribune interview is reprinted in: Pbilip S. Foner, "Two Neglected Interviews with Karl Marx", in: Science \& Society, XXXVI (1972), pp. 3-28. For the section dealing with Bismarck's Anti-Socialist Law, see pp. 27-28.
} 
While discussions were taking place in the press, German-Americans, under the leadership of the Socialist Labor Party, were mobilizing to protest the Anti-Socialist Law and to assist the victims of Bismarck's repression. The SLP was formed when the Marxists, under the leadership of Friedrich Sorge, united with the Lassalleans in July 1876 to form the Workingmen's Party of the United States. In December 1877, at a convention in Newark, New Jersey, the name was changed to the Socialist Labor Party of North America. But the Marxists, disgusted with the domination of the Workingmen's Party by the "political action" Lassallean Socialists and by their indifference, if not outright hostility, to trade unions and the economic struggles of American workers, were not present at the convention. Instead, they joined with Ira Seward and other eight-hour spokesmen to build a mass workingclass organization which would fight for immediate demands around the slogan "Shorter Hours and Higher Wages", with the ultimate aim of abolishing the wage system. For the next several years, the Marxists concentrated on building the short-lived International Labor Union. Several leading SLP figures, such as Albert R. Parsons and George Schilling of Chicago, worked with the Marxists in the International Labor Union, and Professor Adolph Douai, a leading Marxist, continued to maintain close contacts with the SLP through his coeditorship of its German-language organ, the New Yorker Volkszeitung.

But fundamentally, the SLP was under the leadership of the Lassalleans, and the Marxists therefore played no role in the protest movement initiated by the Party against the Bismarck Anti-Socialist Law. Nor were they represented on the National Executive Committee of the SLP which launched the anti-Bismarck protests, and Douai appears to have been the only Marxist of all the speakers who addressed the protest meetings. Since the SLP National Executive Committee made no effort to contact Marx in connection with the anti-Bismarck protests, it is perhaps not surprising that Marx made no mention of them in his correspondence with Swinton. ${ }^{1}$

\section{II}

The first public meeting sponsored by the SLP to express opposition to the Anti-Socialist Law was held in New York City's Germania Assembly Rooms on July 9, 1878. Resolutions were adopted expressing solidarity with the Socialists in Germany "who were suffering imprisonment for having performed their duty in the struggle for freedom", and urging them to continue their struggle "for the overthrow

1 Philips S. Foner, History of the Labor Movement in the United States, I (New York, 1947), pp. 448-53, 493-96, 497-500. 
of militarism - even though prison or exile be their only reward". 1 Clearly this was not enough, and early in January 1879, the SLP National Executive Committee announced the appointment of a Relief Committee "to receive and asist those of our exiled German Comrades, who may need our help". The Party Sections were urged to immediately appoint local committees to raise funds and to send them to the headquarters in New York. The National Executive Committee's plan was to use the funds to finance the emigration of exiled Germans to the United States and to provide them with employment once they arrived. If enough comrades could thus be assured of a secure welcome in this country, it argued, Bismarck's reactionary measures could be defeated. ${ }^{2}$ Since there are no longer any copies of the Socialist papers which published lists of donations from the various sections in existence, it is impossible to determine just how much money was actually raised for this purpose. However, there are references in the non-Socialist press indicating that a number of German Socialist exiles were brought to this country and provided for. ${ }^{3}$

The SLP National Executive Committee also called for "a prompt and energetic protest from all friends of Liberty" in order to demonstrate to the American people that "despite the conspiracies of the Money Power, the hypocrisy of the press, and the treason of our public servants, there are still some true Republicans and Democrats in the United States". The Committee recommended that public mass meetings be held simultaneously in all parts of the country on January 18,1879 , "to express opinions regarding the persecution of our fellowworkingmen in Europe". A set of resolutions "appropriate to the occasion" was sent to each section of the Party. These emphasized that the people of Germany, "now suffering under a despotism most galling", were being victimized because they advocated the very "Republican and Democratic principles upon which our own government is based", and had abstained from "armed resistance" or "violating any laws". Hence it was the "duty of our Republican government to offer, before all civilized nations, a solemn remonstrance against the present policy of the German government, and we therefore call upon the Congress and President of the United States to formally protest against the suppression of civil rights in Germany".4

On February 1, 1879, under the heading "The Goddess of Liberty Aroused", The Socialist, English-language organ of the SLP, published in Chicago, briefly reported the proceedings of meetings held in

1 New York Times, July 10, 1878; Sun, July 10, 1878.

2 The Socialist (Chicago), January 4 and 11, 1879.

${ }^{3}$ New York Times, December 30, 1878; March 12, 1879.

- The Socialist, January 11, 1879. 
response to the call in Boston, New York, Newark, Philadelphia, Baltimore, Cincinnati, Louisville, Indianapolis, Chicago, St Louis and New Orleans, and added that "several others [...] have not yet been officially heard from". In each instance, went the report, "large and enthusiastic audiences packed the various halls to overflowing". While most of the speakers were members of the SLP and several were exiled German Socialists, ${ }^{1}$ a number of non-Socialists, including Lucy Stone, the distinguished woman-suffrage leader, had participated as speakers. In general, the meetings condemned Bismarck, and, using the language contained in the resolutions prepared by the SLP leaders, called upon Congress and the President of the United States "to formally protest against the suppression of civil rights in Germany". They also advised the American people that their protests would serve to warn the forces of reaction in this country not to proceed with plans to institute Bismarckism in the United States. ${ }^{2}$

The most important of these protest meetings were the ones in Chicago and New York. Chicago's Turner Hall was filled, with "quite a number of ladies present". The meeting was chaired by Thomas J. Morgan, and the first speaker was George Schilling. Both were leading trade unionists and members of the SLP. Schilling warned the audience that the success of Bismarck's conspiracy against Socialist ideas would encourage those in the United States who were seeking to "suppress the workingmen and reduce them to slavery". He was confident, however, that persecution could never stamp out "the seeds of Socialism", and that its ideas were bound to spread "throughout the civilized world, and help along the [workingmen's] cause everywhere".

Schilling was followed by Paul Grottkau, leader of the Party in Chicago, who called for pressure on the American government to compel it to register the protests at the various anti-Bismarck meetings by forwarding the resolutions to the German government. Failure to do so, he said, would show that it had "more sympathy for tyrants than it has for the working classes who have made the country what it is". Hon. Chris. Meier, Socialist member of the Illinois legislature, endorsed the proposal, and, like Schilling, stressed the danger of Bismarckism in the United States. Albert R. Parsons, the next speaker,

1 "Comrade Schlesinger, one of the exiled German Socialists", spoke at the Newark meeting; "Comrade A. Gerber of Berlin" addressed the Philadelphia meeting, "Comrade Ludwig Ecks, the exiled Berlin Socialist", closed the Baltimore meeting, and Comrade Florian Bell from Germany performed the same function at the New York meeting. The Socialist, February 1, 1879.

2 A frequent theme was that these plans had increased in number and intensity since the great railroad strike of 1877 was suppressed by the use of federal troops and state militias. Foner, op. cit., pp. 464-74. 
was already becoming disenchanted with the emphasis on political action by the Lassallean-dominated SLP. He was soon to split with the Party, join the Anarchists, and take the road which led in 1886 to his death as one of the Haymarket Martyrs. Parsons delivered a fiery speech, in which he declared that the vast protest meeting "denoted a new era in the world's civilization when men in different lands, of different nationalities, were impelled to espouse each other's cause and protest against wrong and oppression". Predicting that "the floodgates of revolution are about to be opened all over the world", Parsons insisted that the people should not ask for their rights on bended knees, "but stand up like men and demand them, though the heavens fall". Like the preceding speakers, he stressed the danger of Bismarckism in the United States, and warned that the rights of American workers, especially "free speech, free press and the right to organize", were in danger of being destroyed by the monopolists, just as their right to the soil had already been robbed by "the land-thieves". Himself a member of the Lehr und Wehr Verein, the armed club formed by the German Socialists of Chicago to defend workers from police and militia brutality, 1 Parsons advised workers that they must keep "their trusty rifles within reach. They must mean what they said, and then the capitalistic class would know that when they said that the bayonet and halter waited those who tried to crush the laboring class, they meant it. They would then begin to respect their rights."

A calmer note was struck in a song written for the occasion and sung by its composer, W. B. Creech. Sung to the tune of Yankee Doodle, it went:

Workingmen assembled here, No matter what your nation, Raise your voices now against Old Bismarck's cowardly action;

How he banished honest men.

For their love of freedom.

Far from home and fatherland,

With meanest persecution.

Yankee Doodle welcomes all

To our glorious Union,

Where from Bismarck's power you're free

Or any nation tyrant.

1 The SLP National Executive Committee frowned upon these armed clubs and in 1878 all members were ordered to leave, but this order was resented by many Socialists in Chicago and intensified the schism in the Party. 
Bismarck and his dogs of war

Germany are searching

For our Socialist boys,

To stop their agitation;

But as soon as one is stop't,

Twenty stand defiant,

To denounce him and his chains -

This mighty prince of tyrants.

Bismarck now is badly beat

By the German people;

Better he had changed his laws,

And made them just and equal.

Give the workingmen their rights -

Some day you may need them;

Think of France - we're brothers now

In Socialistic union.

After the unanimous adoption of resolutions condemning the AntiSocialist Law, the meeting took up a collection for the benefit of the four exiles from Germany who were present. The chairman then declared the meeting adjourned, and "the large assemblage dispersed". ${ }^{1}$

The protest meeting in New York City was called by a committee of Socialist and liberal reformers, headed by John Swinton, and the call stated its object was to

"enter a protest of the citizens of New York against the oppressive and infamous policy now enforced upon the people of Germany a policy which deprives them of their liberties, the liberty of thought, of speech, of the press, and of assembly which is incarcerating them in prison, driving them into exile, and subjecting them to untold suffering, and which is disgraceful to the nineteenth century and the spirit of justice.

The people of the city, without regard to differences of party or race, who see the rights of all men involved in the rights of German Democracy and who approve of a protest against the recent despotic measures of Bismarck being sent from the United States, are invited to be present, January 22, 1789, at Chickering Hall, 981 Fifth Avenue."2

The sponsoring committee had hoped to hold the meeting in the more convenient Steinway Hall, which was more often used for such

1 The Socialist, January 25, 1879.

2 Sun, January 23, 1879. 
gatherings, or in the Academy of Music, but they were denied these facilities by the managements "on account of the character of the gathering". To the surprise of many New Yorkers, the management of the prestigious Chickering Hall on Fifth Avenue agreed to rent its facilities. As Swinton commented wryly, Socialists "had been routed out of First Avenue, clubbed out of Tompkins Square, and subjected to the most infamous outrages in the Democratic regions of the east side, and now they propose to establish their headquarters in the avenue of the aristocracy". ${ }^{1}$ The reference to Tompkins Square was to the brutal police attack of January 13,1874 , on the unemployed demonstration called by a committee representing sections of the First International and trade unions. ${ }^{2}$ It was after this tragic event that Swinton had made his first public address on behalf of the working class at the Cooper Union meeting protesting the police action. ${ }^{3}$

Swinton both chaired the meeting and delivered the main address. His speech was so highly regarded that the SLP not only had it published in its entirety in each of its papers, but issued it separately as a pamphlet. Swinton made it clear that it was not necessary for one to uphold the principles of the Social Democrats in Germany to protest Bismarck's anti-Socialist measures. Why, he asked, must all Americans, regardless of their political views, join in such protests? And he answered:

"Well, in the first place, we thus proclaim the unity of man, and of Liberty, and of public justice, and of all human interests, and of the world's welfare. We proclaim that there is not a tyrant on earth but wrongs every member of the human race; that when the body of Liberty is wounded in any part, all the other parts suffer with it; that the adoption or enforcement of an evil measure by the government of any country affects the fortunes of every country; and that all men are directly concerned in the oppression of any man. In the second place, we thus signalize our readiness to condemn, denounce, and confront every new pretence and assault of despotism upon the body of Liberty anywhere. In the third place, we thus proclaim our power and purpose to offer sympathy wherever there is suffering, and to uphold the hands of those who, in any part of this earth, stand for the cause that recognizes no geography, no ethnology, no frontiers, no an-

${ }^{1}$ Ibid.; New York Herald and New York Tribune, January 23, 1879.

2 Herbert G. Gutman, "The Tompkins Square 'Riot' in New York City of January 13, 1874: A Re-examination of Its Causes and Its Aftermath", in: Labor History, VI (1965), pp. 44-70; Foner, op. cit., pp. 447-48.

3 Sun, January 31, 1874. 
tagonistic politics or laws or interests. In the fourth place, this kind of thing is of the nature of that intrepid and aggressive Americanism which used to be more frequently made manifest than it is now."

Swinton made no effort to hide the fact that when he spoke of wounds suffered by the body of Liberty, he was not only referring to Europe but that here, too, in the United States, the rights of the people were being increasingly trampled underfoot by the same reactionary forces which were in control of the government in Germany. After tracing Bismarck's career, studded with the destruction of freedom in many parts of Europe as well as Germany, Swinton condemned those, including many German-Americans, who adulated the man of blood and iron because he had transformed Germany into a mighty nation. It were better for Germany, he cried, had Bismarck "never been born". It was not for the American people to tell their "Democratic brethren in Germany" what policy or action to adopt to meet and defeat Bismarckism. "It is but ours, who can speak, to say a word for them now dumb; it is but ours to send them a spark of that sympathy which makes kin of all the sufferers for liberty throughout the world. Doubt not that it will be welcome. Not all the enginery of German law can keep out of Germany the echoes of the hundred meetings of protest and sympathy that have been and will be held in the United States."

After Swinton's moving speech, the secretary read a letter from Douai in which the Marxist educator called for support of the Socialists in Germany, and predicted that German Social Democracy "will only be strengthened by this persecution. Social Democracy is used to this." Social Democracy was still alive in Germany, in spite of Bismarck, he declared, and it would continue to live long after Bismarck. Douai's letter closed with the call: "Long live Social Democracy." Henry Drury and Charles Pinnel followed with speeches in French; Leopold J. Palda, editor of Délnické Listy, spoke in Bohemian, and George Winter addressed the meeting in German. All four stressed the danger of Bismarckism in the United States, called for support for the victims of repression in Germany, and predicted the ultimate triumph of Socialism. The final speech was by Florian Ball, an exile from "the Bismarckian police", who spoke in German. He expressed gratitude in the name of his comrades for "this splendid demonstration". $\mathrm{He}$ was too overcome "by this outpouring of the masses" to present his feelings in detail. But even if the protest meeting did not have an immediate effect "on the tyrants of Berlin", it was "a warning against tyrants everywhere; aye, even to those in this country, if such there 
be, that the people are everywhere marching on to freedom. All hail to human rights!"

The resolutions adopted by overwhelming vote - there was only one "nay" - called the Anti-Socialist Laws "disgraceful to the German government, and [...] have made the name of their author a hissing and a reproach throughout the world". They offered "the strength" of the American people for the support of its victims who were "suffering and speechless", or "in prison or in exile", and ordered that copies of the resolutions be sent to the Federal authorities in Washington for transmission to the Berlin Government, the Federal Council of Germany, the German Parliament and Chancellor Bismarck. ${ }^{1}$

The proceedings of the Chickering Hall protest meeting were fully reported on the front pages of almost every New York newspaper under such headlines as "Bismarck Denounced", "The Anti-Bismarck Protest", "The Socialist Meeting - Bismarck Fiercely Denounced". The Socialist carried its account of part of the proceedings under the headlines:

"Despotism Denounced - Five Thousand Socialists in Chickering Hall, New York City Protest Against The Brutal And Oppressive Acts of German Imperialism - American Citizens Sending Sympathy and Encouragement To Their German Brethren".2

While New York papers did not agree on the exact number present reports varied from two thousand to "over 3,500" - they did acknowledge that the meeting was well attended, and one even viewed it "as by far the most successful meeting ever held by the socialists in New York City". " "Never before was there such a Democratic gathering in Fifth Avenue as that which crowded Chickering Hall before 8 o'clock last night", wrote the reporter for the New York Sun. "Soon after the doors were opened the hall was filled to overflowing and many people were unable to find admission." ${ }^{4}$ Even the New York Times, which presented an extremely hostile, editorialized account rather than a report of the actual proceedings, conceded: "Every seat was filled, and the walls were lined by persons standing." 5 Several papers noted the fact that "many women" were in the audience. The New York

1 This account of the meeting is based primarily on the New York Herald, which carried the fullest details in its issue of January 23, 1879. Other accounts appeared in the Sun, World (New York), New York Tribune, New Yorker Volkszeitung and New York Times of the same date. Of the leading New York papers, only the Evening Post (New York) carried no report of the meeting.

2 The Socialist, February 15, 1879.

${ }^{3}$ New York Herald, January 23, 1879.

4 Sun, January 23, 1879.

${ }^{5}$ New York Times, January 23, 1879. 
correspondent of The Socialist called the meeting "the best of the kind ever held in New York", adding that it was "not merely a good meeting; it was a triumph for the party". "The New Yorker Volkszeitung hailed the gathering editorially as an outstanding example of internationalism and as proof "that the spirit of freedom in the American people has not been extinguished". ${ }^{2}$ But only one non-Socialist New York paper carried an editorial - the New York Times. It had a lengthy comment on January 24, 1879 - much longer, in fact, than the space it devoted to the proceedings at Chickering Hall -, the main theme of which was that the German-American Socialists had let down their harassed comrades in Germany by failing to show up in large numbers. "There was no lager at Chickering Hall the other night", it scoffed. "Neither was there any German Socialists." The Times editorial writer appears not to have read the account of the meeting in his own paper, since the reporter repeatedly stressed the fact that the majority of the people in the audience were German-Americans who loudly applauded every reference to Socialism.

The Chickering Hall meeting had an interesting sequel. Swinton, it will be recalled, had declared that not all "the enginery of German law" would be able to keep out the "echoes" of the protest meetings in the United States, and he set about to prove his point. On February 28, 1879, he forwarded printed copies of his speech at the Chickering Hall meeting to every American consul and commercial agent in the German Empire. His purpose was to ascertain whether Bismarck would abide by the Berne Postal Treaty, under which the delivery of German and American mails were regulated. Would the Chancellor prohibit the free use of the mails in Germany by an American citizen resident in the United States and the official agent of that citizen's government resident in Germany, if this mail also included the type of "obnoxious" correspondence that was being confiscated on Bismarck's orders? In April 1879, Swinton released the correspondence he had received from American consuls in Germany, deleting their names. One indicated that as of March 17, 1879, the printed copy of Swinton's speech had not been delivered, and expressed doubt that "it will ever reach me". $\mathrm{He}$ added that in his opinion the German government had the right to exclude from the mails all "seditious literature", and that no one would dispute "that in Germany any and every publication which advocates or defends Socialist theories [...] would be classed among seditious literature". Another American consul notified Swinton that

1 The Socialist, February 8, 1879.

2 "Against Bismarck and His Supporters", in: New Yorker Volkszeitung, January 23, 1879. 
he had received the package and that it had not been inspected by the German authorities, and he expressed the certainty that had it been inspected, the documents would never have reached him. "Your speech", he closed, "is lively reading, and would certainly come under the ban here."

Swinton had made his point: even the rights of American citizens, established by treaty, were being trampled by the Iron Chancellor. But he was furious at the refusal of American officials in Germany to condemn any interference with the use of the mails by American citizens, a right guaranteed under the Berne Postal Treaty. He did not, as did the Chicago Times and a number of other newspapers, regard the affair as "a joke", and he told a reporter for the New York Graphic, which published his correspondence with the American consuls, that he would like the American government to ask Bismarck "if he proposes to violate or to abrogate the Berne Postal convention, into which he entered with our government. If he does not, let him be held to the terms of the convention; and in any event, let the rights of all the parties to it be maintained with equal fairness on every hand." The Graphic editorially endorsed Swinton's demand:

"In all seriousness there is enough in this controversy to warrant the State Department in giving Minister Andrew D. White such instructions, that if he has backbone and is more desirous of serving the American people than of currying favor with the German Court, would result in settling a very important point of international law. Will Mr. Secretary of State William M. Evarts examine the subject and intimate to Minister White his wishes in regard to it? Fame follows boldness. Every extension of liberty has been wrung from adverse conservatism. Webster and Marcy did not hesitate. They took the side of freedom. Will Mr. Evarts follow their example? Or will he let this opportunity pass away unimproved?"1

Even though nothing was done, this was not the last the German government was to hear of protests in the United States against the anti-Socialist law.

\section{III}

In the opening months of 1880 , Charles Stewart Parnell, leader of the Home Rule Party in Ireland and supporter of the Land League, made a highly successful tour of several cities in the United States in behalf of the Irish liberation struggle. Enthusiastic audiences greeted Parnell

1 Graphic (New York), April 12, 1879. 
in New York, Philadelphia, Newark, Boston and other cities, and a considerable sum of money was raised for the cause in Ireland. ${ }^{1}$ Undoubtedly influenced by the success of Parnell's visit and the response of Irish-Americans to the needs of their motherland, the Social Democratic Party of Germany, at its first illegal Congress in Castle Wyden, Switzerland, in the summer of 1880 , voted to send a delegation to the United States "for the purpose of informing the German-American working men of the condition of the party under the anti-socialist law, and collecting funds for the approaching elections to the German Diet". ${ }^{2}$ The delegation consisted of Friedrich Wilhelm Fritzsche and Louis H. Viereck.

Fritzsche, a native of Leipzig, founded the union of cigar-workers in December 1865, the first new national organization of German workers established since the Revolution of $1848-49 .^{3} \mathrm{He}$ was elected to the Reichstag on July 24,1869 , and was re-elected several times on the Social Democratic ticket. In his Chicago Tribune interview of January 5, 1879, Marx listed Fritzsche as one of the "forty-eight prominent men" expelled from Germany. Marx also had reference on a different occasion to Louis $H$. Viereck (reported to be the illegitimate son of Emperor Wilhelm), who became a Social Democratic lawyer and journalist. Viereck was supposed to convey Marx's "compliments" to Swinton upon his arrival in the United States, but, as Marx informed Swinton, he became "so stultified" that he confused Engels with Marx and transformed the latter's compliments into those of the former. "He did the same with regard to another American friend of mine by whose letter I was informed of the quid pro quo [exchange]."4

Fritzsche and Viereck arrived in the United States on February 5, 1881, and departed for Germany on April 23. They were warmly received by delegations from the SLP and trade unions, and addressed mass meetings in New York, Paterson, Newark, Philadelphia, Detroit, Chicago and Boston. With the exception of the Evening Post and the World, the leading New York English-language papers carried accounts of the meetings in that city, ${ }^{5}$ but the Newark, Philadelphia, Detroit and Chicago press ignored them. Not even the Chicago Tribune, which had featured the interview with Karl Marx in January 1879, could

1 New York Times, January 3, 5, 9 and 10, March 12, 1880.

2 Morris Hillquit, History of Socialism in the United States (New York, 1910), p. 208.

${ }^{3}$ Geschichte der Deutschen Arbeiterbewegung (Berlin, 1966), I, pp. 208, 234, 267.

4 Marx to Swinton, June 2, 1881, Letters to Americans, p. 127.

S Sun, February 6, 1881; New York Herald, New York Times and New York Tribune, February 14, 1881. 
find room for the activities in behalf of Marx's persecuted colleagues. If not for the reports by correspondents of the New Yorker Volkszeitung in several cities where the two German visitors spoke, these meetings would have gone unrecorded. ${ }^{1}$

The Boston meeting was held in that city's famous "Cradle of Liberty" - Faneuil Hall - and was called by the SLP "to protest against the oppression of liberty in Germany". ${ }^{2}$ The meeting marked the first time Swinton spoke in Boston. He shared the platform with Fritzsche, Viereck, and with the great Wendell Phillips. Phillips had been famous before and during the Civil War for his distinguished role as an abolitionist and a champion of full equality for blacks in American life. Once the war was over, he turned his attention to the relations between labor and capital, advocated independent political action by labor, and was active in the movement for the eight-hour day. Growing increasingly convinced that the evils of capitalism could only be ended through a new social system, Phillips became more and more interested in socialism. He defended the Paris Commune (he was one of the few leading American public figures to do so) and after offering to lecture without a fee for the International Working Men's Association, he joined the Boston section of the First International. In the minutes of the General Council of the organization for August 15, 1871, there is the following entry: "The most important item of news was that Wendell Phillips, the great anti-slavery leader, had joined the ranks of the International." 3

Phillips began his speech at the anti-Bismarck meeting by paying tribute to the German-Americans for their magnificent contributions in defense of the abolitionists during the bitter struggle against slavery. He reminded the audience that in 1861, "when free speech in this city, Boston was trampled under foot; when there was hardly a

1 Accounts of the meetings in Paterson and Newark appeared in the New Yorker Volkszeitung, February 12 and 24, 1881; brief accounts of the meetings in Philadelphia, Chicago and Detroit appeared in issues of February 28, March 24 and April 6, 1881. The Volkszeitung published the full proceedings of the meetings in New York and a partial account of the gathering in Boston in its issues of February 14, 19 and 21, March 8 and 9, 1881. It carried the reports of all meetings under the heading "Für die Freiheit Deutschlands".

${ }^{2}$ Boston Advertiser, March 8, 1881.

s The General Council of the First International, Minutes, 1870-1871 (Moscow, n.d.), pp. 52, 258. There is some doubt as to whether Phillips actually became a member of the International. Samuel Bernstein is not certain that this actually happened, The First International in America (New York, 1965), p. 26. Actually, Phillips's espousal of currency reform as the solution for labor's problems, a program the Marxists in the International vehemently opposed, makes it unlikely that he would have remained in the Association long even if he did join. 
journal that would defend, or a roof that could protect the opponents of slavery, the German Turners ${ }^{1}$ passed a resolution to protect free speech and free speakers, and night after night they marched in squads and saw to it that free speech was not trodden out." He owed it to the vigilance of the Germans that free speech survived that disastrous winter. A year later, when a mob in Cincinnati had interrupted his speech against slavery in the Music Hall, "and covered me with stones and eggs", and when the Mayor of the city refused to order the police to protect his right to speak, "it was the German Turners who, on the day following, said: 'Come back tonight, and we will give you 1000 Germans for Police, and see that no mob drowns your voice"'. The German-Americans, Phillips pointed out, were also among the foremost defenders of the Union when the slave power sought to destroy it following Lincoln's election to the presidency in 1860. The Germans "secretly at midnight drilled for a whole six months previous to the fall of Sumter, and let St. Louis know that if she was ever plucked from the Stars and Stripes she must go over the bodies of the Germans". ${ }^{2}$ In part, therefore, he said, his presence at the meeting in Faneuil Hall was to show his gratitude for the heroic defense of freedom in the United States by German-Americans. He declared that while he believed that peaceful methods would suffice to achieve social change in the United States, those who sought to gain freedom from tyranny in Europe had the right to decide for themselves what methods they believed were necessary to achieve their goal:

"At this distance I don't mean to criticize methods. I look at Russia, 4000 miles away, and see what an incubus is resting on her people. I only hope that somebody will lift it off their shoulders. If nothing will do it but the dagger, then welcome the Dagger!

Is there an American here who thinks that bad? Let him look there at Joe Warren ${ }^{3}$ [pointing to a picture on the wall], who died at Bunker Hill."

Tremendous applause swept the audience.

Before adjourning, the meeting unanimously adopted resolutions

1 Turners were originally German-American singing associations. Under the influence of the Socialists, the Turners became the most effective opponents of slavery in the labor movement. See Herman Schlüter, Lincoln, Labor and Slavery (New York, 1913), pp. 75-76, and Foner, op. cit., pp. 278-96.

2 Although a slave state, Missouri did not secede and join the Southern Confederacy during the Civil War. As Phillips noted, the German-Americans played an important role in keeping Missouri in the Union.

${ }^{3}$ Joseph Warren (1741-75) was a Massachusetts physician, leader of the revolutionary struggle against England, who was killed while serving as major general at Breed's Hill during the Battle of Bunker Hill. 
arraigning "Bismarck and the German government" for having, in the time of peace, "deprived a million of German citizens of that right of peaceably assembling, of forming organizations, and of the liberty of the press [...] which is guaranteed to all Germans by the constitution of the Empire"; for having "cruelly banished" hundreds of Germans and forced them and their families into "crushing poverty, for the sole reason, that these men hold political opinions unpalatable to the ruling powers". The resolutions also condemned the pretext used by Bismarck to justify the persecution of the Socialists, and asserted that it was "evident [...] that the growing strength of the party and not any criminal conspiracy is the real reason for the vindictiveness exhibited". Finally, the resolutions held out "a sympathizing hand to the Socialists in Germany [...] and [we] recommend them to the aid and comfort of our fellow citizens who hitherto have always had an open hand and a warm heart for oppressed people". ${ }^{1}$

According to the Boston papers, between fifteen hundred and two thousand people were present at the meeting, which was considered a good attendence, especially in view of the inclement weather. The Labor Standard, published in Fall River, Massachusetts, even called it "an immense meeting". Most Boston papers carried reports of the meeting under such headlines as "German Socialists - Sympathetic Meeting at Faneuil Hall"; "The German Socialists - Mass Meeting of Germans in Faneuil Hall". ${ }^{2}$ The Boston Advertiser stressed the fact that most of the audience "appeared to understand the German language", ${ }^{3}$ leaving the impression that there were not many present besides members of the German-American community. The Labor Standard, however, reported that there was a good representation of non-German workers in the audience, and its account of part of the proceedings appeared under the headline: "Freedom For Fatherland The Cradle of Liberty Rocks For Germany".4

The Boston meeting made international news. A summary report of the proceedings, headed "Fritzsche und Viereck in Amerika", appeared in Der Sozialdemokrat, the organ of the Social Democratic Party of Germany, published (in exile) in Zurich, Switzerland. ${ }^{5}$ Moreover, Frederick Engels, furnished with a full report of the meeting by George Julian Harney of Boston, ${ }^{6}$ was impressed by the size of the

1 Boston Globe and Boston Herald, March 8, 1881.

2 Boston Post and Boston Traveller, March 8, 1881.

3 Boston Advertiser, March 8, 1881.

4 Labor Standard (Fall River, Mass.), March 12, 1881.

- Der Sozialdemokrat (Zurich), March 27 and April 17, 1881.

- G. Julian Harney to Frederick Engels, Cambridge, near Boston, March 11, 1881, in The Harney Papers, ed. by F. G. Black and R. M. Black (Assen, 1969), p. 239. 
meeting and the response of "our American friends". Writing to August Bebel, Engels called the meeting "brilliant", noting the attendance of some fifteen hundred people, one-third of whom were Germans. He mentioned the speech of Swinton, whom he called "an American Communist" (a characterization Marx did not employ), referred to Fritzsche, but devoted most of his report to Phillips. He described Phillips as "a great anti-slavery man who, except for John Brown, did more than anyone else for the destruction of slavery and for victory in the war against the slaveowners", and called him "the first orator in the Americas, and perhaps the world". After mentioning that Phillips had expressed gratitude for the contributions of the German-Americans in the struggle against slavery, Engels quoted Phillips's observation that he was in no position to criticize the methods used in Europe against tyranny, and his assertion that if nothing would end tyranny in Russia but the dagger, "then welcome the Dagger!" Then Engels commented: "That was on March 7. On the 13th, the bomb accomplished what the dagger could not."2 Engels concluded his discussion of the Boston meeting with these words: "All told, the success exceeds my expectations and shows that even with the Germans, solid citizens, the whole Bismarck business has lost its appeal."3 Engels knew that there existed among the German émigrés in the United States a strong pro-chauvinist and pro-nationalist pride in Bismarck's military conquests, ${ }^{4}$ and he felt that the success of the meetings protesting Bismarck's Anti-Socialist Law was a sign that this narrow, reactionary outlook was on the decline.

At the 1883 convention of the Social Democratic Party of Germany, held in Copenhagen, Bebel reported that the Fritzsche-Viereck tour had netted 13,000 marks and had been "a great help" to the Party. "We are very grateful to the American Comrades", he continued, "who supported this enterprise, and I herewith express this gratitude

1 In his letter to Sorge, November 5, 1880, Marx characterized Swinton as a friend of, but not one of the Socialist movement; essentially he was a "wellmeaning bourgeois". Letters to Americans, pp. 123-26. Swinton may have been a member of the SLP, for in a letter to the Party's Executive Committee he signed himself as "Your Comrade", and The Socialist of Chicago referred to Comrade John Swinton" in ite issues of April 5 and December 21, 1879.

2 The reference, of course, was to the assassination of Tsar Alexander II on March 18, 1881.

Engels to Bebel, March 30, 1881, in Karl Marx, Friedrich Engels, Werke, Vol. 35 (Berlin, 1967), pp. 174-75.

4 The General Council of the First International, Minutes, 1871-1872 (Moscow, n.d.), p. 400 . 
in the name of all present." The statement was greeted by a chorus of "Bravo"."

Morris Hillquit, historian of American Socialism, has written that the Fritzsche-Viereck tour had also been a great help to the SLP in the United States, and that their tour, "although undertaken for a different purpose, had the effect of reviving the local socialist movement". ${ }^{2}$ Engels, however, believed that by the nature of their speeches, Fritzsche and Viereck had strengthened the reformist tendencies in the SLP. When the question of another fund-raising journey to the United States by representatives of the German Social-Democracy arose in 1884, Engels urged that this time only reliable men like Bebel and Liebknecht be sent. No amount of money raised could "make up for the harm that would be done" if the people who went spread "vulgar democratic" ideas like those disseminated by Fritzsche and Viereck during their tour. ${ }^{3}$ He particularly had in mind Fritzsche's tendency, in interviews and speeches, to play down the revolutionary content of the German Social-Democratic Party's platform with its demand for Socialism, and to emphasize only its call for such reforms as the separation of church and state, universal free education, social measures in behalf of the workers, such as workmen's compensation and abolition of child labor, and the abolition of standing armies and the substitution in their place of people's militias. ${ }^{4}$

One thing, however, is certain. The activities it organized against the Anti-Socialist Law from 1878 to 1881 marked the first time since its formation late in 1877 that the SLP received widespread attention in leading newspapers. This, in turn, brought the ideas of the Socialists to a much wider audience than the Party could ordinarily reach.

The protests in the United States against Bismarck's Anti-Socialist Law represent both an important chapter in the history of German-

1 Protokoll über den Kongress der Deutschen Sozialdemokratie in Kopenhagen abgehalten vom 29 März bis 2 April 1883 (Zurich, 1883), pp. 11-12.

${ }^{2}$ Hillquit, op. cit., pp. 208-09. Hillquit is referring only to the 1881 meetings. He makes no mention of the meetings sponsored by the SLP in 1879 to protest the Anti-Socialist Laws.

Engels to Bebel, January 18, 1884, in Werke, op. cit., Vol. 36, p. 86. Although plans were made in the spring of 1884 for Bebel and Liebknecht to go to the United States, they fell through. Liebknecht, however, did go to the United States in the spring of 1886 . He was invited by the SLP National Executive Committee, and arrived in the United States on September 13, 1886. His visit coincided with that of Eleanor Marx-Aveling and Edward Aveling, Marx's daughter and son-in-law.

4 New York Tribune, February 6, 1881; Sun, February 14, 1881; and Boston Globe, March 8, 1881. The Boston Globe carried both an interview with Fritzsche and the full text of his speech in Faneuil Hall, and Engels obtained copies of the papers from Harney. The Harney Papers, op. cit., p. 293. 
Americans and a significant example of international working-class solidarity. Carl Wittke, a leading historian of German-Americans, mentions what he calls "isolated protests" against Bismarckism, but notes that they made "almost" no impression "upon the Germans in the United States". 1 But he totally ignores the protest in many American communities with large German populations against Bismarck's Anti-Socialist Law. The New Yorker Volkszeitung viewed the protest movement as important not only for the contribution it made to the struggles of the Socialists in Germany, but also because it heightened the entire cause of international labor solidarity. It predicted that the anti-Bismarck protests would prove to be the first step leading to the formation of a new international organization of Socialists. ${ }^{2}$

1 Carl Wittke, Refugees of Revolution: The German Forty-Eighters in America (Philadelphia, 1952), p. 364.

${ }^{2}$ New Yorker Volkszeitung, February 14, 1881. 